\title{
Influence of Fruit Maturity, Cultivar Susceptibility, and Inoculation Method on Infection of Olive Fruit by Colletotrichum acutatum
}

\author{
J. Moral, K. Bouhmidi, and A. Trapero, Departamento de Agronomía, ETSIAM, Universidad de Córdoba, Campus \\ de Rabanales, 14071-Córdoba, Spain
}

\begin{abstract}
Moral, J., Bouhmidi, K., and Trapero, A. 2008. Influence of fruit maturity, cultivar susceptibility, and inoculation method on infection of olive fruit by Colletotrichum acutatum. Plant Dis. 92:1421-1426.

Detached olive (Olea europaea) fruit inoculated with isolates of Colletotrichum acutatum, causal agent of olive anthracnose, were used to study host-pathogen interactions. Fruit susceptibility increased with increasing fruit maturity. Wounded fruit were more severely affected than nonwounded fruit; however, the wound effect depended on cultivar and inoculation method. Severity of fruit infection increased with inoculum density, although this effect also depended on fruit maturity and cultivar susceptibility. The susceptibility of selected olive cultivars to anthracnose under field conditions correlated well with the response of immature fruit under controlled conditions. As fruit matured, there were fewer differences among cultivars. Based on these results, an inoculation method using immature green fruit and high inoculum densities (10 $10^{5}$ to $10^{6}$ conidia/ml) sprayed on the fruit has been proposed to evaluate olive cultivars for anthracnose resistance under controlled conditions.
\end{abstract}

Additional keywords: aceituna jabonosa, Colletotrichum gloeosporioides, fruit rot, Gloeosporium olivarum

The Spanish olive industry presently comprises over 2.5 million ha with an annual olive oil production value exceeding $\$ 3.6$ billion in the last 4 years (24). Anthracnose of olive (Olea europaea L.) is the most destructive disease of olive fruit and it is widely distributed in many olive-growing regions of the world $(11,18)$. In Spain, the disease is named for its characteristic fruit rot syndrome, with abundant production of conidia in a gelatinous matrix ("aceituna jabonosa" or "soapy fruit") under wet conditions (11,27). Most of the affected fruit fall prematurely to the ground and only a few of them remain mummified on the tree canopy $(15,18,41)$. Anthracnose can affect up to $100 \%$ of the fruit on a tree, particularly in years with wet autumns and where susceptible cultivars are grown (40-42). Moreover, a very poor olive oil quality is obtained from olives harvested in anthracnose-affected areas because of alterations in oil color (red), acidity, and organoleptic characteristics $(11,16)$. In addition, dieback of branches and defoliation result in yield reduction $(10,18$, 31,41).

Corresponding author: A. Trapero

E-mail: trapero@uco.es

Accepted for publication 10 June 2008.

doi:10.1094/PDIS-92-10-1421

(C) 2008 The American Phytopathological Society
Two species of Colletotrichum, Colletotrichum acutatum J.H. Simmonds and $C$. gloeosporioides (Penz.) Penz. \& Sacc., are the causal agents of olive anthracnose $(25,26,40)$. In Portugal, Talhinhas et al. (40) reported that $C$. acutatum is the dominant species, with very limited occurrence of C. gloeosporioides. However, morphological and physiological characteristics that are intermediate between those of $C$. acutatum and C. gloeosporioides have been observed in isolates from southern and central Italy and southern Spain $(1,35)$.

Extensive studies have been conducted to determine the effects of several variables on infection and lesion development, yield losses, and management of diseases caused by Colletotrichum spp. in other crops $(7,13,20,28,34)$. However, the influence of environmental and host conditions are not well known for olive anthracnose. Although Mateo-Sagasta (27) demonstrated that black fruit are more susceptible to anthracnose than green fruit, the relationship between maturity and susceptibility of fruit has not been established. Wounding is another factor that affects fruit infection by Colletotrichum spp. (5). Colletotrichum spp. can infect wounded or nonwounded olive fruit $(17,18,23,27)$ but wounding may modify the resistance of some cultivars to anthracnose (27).

Olive cultivars such as Frantoio, Manzanilla de Jaén, Tempranillo, and Verdial de Huévar have been commonly identified as either resistant or susceptible to anthracnose, depending on the observer or the site
$(11,27,29,42)$. Hence, an effective method to evaluate the resistance of olive cultivars under laboratory conditions and a continuous assessment in the field are needed in order to clarify these discrepancies.

The main objective of this study was to identify the optimum conditions to assess olive cultivars for anthracnose resistance under controlled conditions. The specific objectives were to determine the effects of fruit maturity, wounding, inoculum density, and inoculation method on infection of olive fruit by $C$. acutatum under controlled conditions favorable for infection and disease development.

\section{MATERIALS AND METHODS}

Olive fruit. Olive fruit were collected from healthy field-grown trees in the provinces of Córdoba and Jaén (southern Spain). Fruit of the following five widely grown olive cultivars with different degrees of resistance to anthracnose (6) were used: Picudo (highly susceptible), Hojiblanca (susceptible), Arbequina (moderately susceptible), Picual (resistant), and Frantoio (highly resistant) (29). All cultivars are considered native to Spain except Frantoio, which is native to Italy (6). Olive fruit were separated into six color classes from 1 (green or immature fruit) to 6 (black or mature fruit) (22). Olive fruit were washed, surface sterilized by immersing them in a $10 \%$ solution of commercial bleach $(\mathrm{Cl}$ at $50 \mathrm{~g} / \mathrm{liter})$ in sterile water for $1 \mathrm{~min}$, and allowed to air dry on a laboratory bench. Disinfested fruit were placed on plastic containers and stored at $4^{\circ} \mathrm{C}$ until used (less than 7 days). Disinfested fruit were preconditioned at room temperature $\left(23 \pm 2{ }^{\circ} \mathrm{C}\right)$ for 4 to $6 \mathrm{~h}$ prior to inoculation with $C$. acutatum.

Isolates. Isolates Col-10 and Col-87 of the pathogen used in the different experiments were obtained from fruit on diseased olive trees from Córdoba and Málaga provinces, respectively, in southern Spain. Both isolates exhibited morphological and physiological characteristics intermediate between those of $C$. gloeosporioides and C. acutatum, although the characteristics were closer to $C$. acutatum morphospecies (35). They were identified as $C$. acutatum because their internal transcribed spacer (ITS) and 5.8S region of rDNA showed complete homology with the reference isolate IMI-351255 of C. acutatum (unpublished data). These isolates are representative of the Spanish population of the 
pathogen because $98 \%$ of isolates previously obtained from anthracnose-affected olives in southern Spain were identified as the $C$. acutatum morphospecies (35). Single-spore isolates were cultured in petri dishes containing potato dextrose agar (Difco Laboratories) acidified with lactic acid $(25 \%$ [vol/vol] at $2.5 \mathrm{ml} / \mathrm{liter}$ of medium). Petri dishes were incubated at $23 \pm$ $2^{\circ} \mathrm{C}$ with a 12 -h photoperiod of fluorescent light $\left(40 \mu \mathrm{mol} \mathrm{m}{ }^{-2} \mathrm{~s}^{-1}\right)$ for 1 week. To ensure that the conidia used were viable, germination of each batch of inoculum was measured prior to inoculation. Inoculum density of $C$. acutatum was measured with a hemacytometer and adjusted to $10^{6}, 10^{5}$, $10^{4}, 10^{3}, 10^{2}$, and 10 conidia/ml depending on the experiment.

Wounding, inoculation, and incubation. Wounded and nonwounded fruit were included in the different experiments. Three wounds $(2 \mathrm{~mm}$ deep and $0.8 \mathrm{~mm}$ wide) were made on each fruit with a sterile needle before inoculation. Fruit were inoculated by two methods: immersion in a conidial suspension for $30 \mathrm{~min}$ or by spraying with a conidial suspension (about $0.7 \mathrm{ml}$ of inoculum was sprayed on each fruit). In all experiments, control fruit were immersed or sprayed with sterile water. Inoculated and control fruit were incubated in humid ( $100 \%$ relative humidity) plastic containers ( 22 by 16 by $10 \mathrm{~cm}^{3}$ ) placed in growth chambers at $23 \pm 2{ }^{\circ} \mathrm{C}$ under fluorescent lights (12-h photoperiod, $40 \mu \mathrm{mol}$ $\left.\mathrm{m}^{-2} \mathrm{~s}^{-1}\right)$.

Effect of fruit maturity. To test the relationship between fruit maturity (color class) and fruit susceptibility, olive fruit from six color classes (from green to black) of the susceptible cv. Hojiblanca were inoculated by immersing them in a conidial suspension $\left(10^{6}\right.$ conidia/ml $)$ of isolate Col-10 for $30 \mathrm{~min}$. Wounded and nonwounded olive fruit were included in this experiment. The full factorial combination (six by two) of treatments was arranged in a completely randomized design with two replicates (humid chambers) per treatment and 20 fruit per replicate. The humid chambers were incubated at $23 \pm$ $2^{\circ} \mathrm{C}$ and the disease incidence (fruit with unequivocal symptoms of anthracnose) was assessed 7 and 14 days after fruit inoculation. The experiment was performed twice, and data presented are the average of the two experiments because error variances were homogeneous and there were no significant differences between the experiments. Linear regression analyses were used to evaluate relationships between maturity of fruit (color class) and disease development 7 days after inoculation. Comparison of the regression lines of fruit with and without wounds was made that considered homogeneity of variances, slopes, and elevations. The effect of color class on incidence of disease 14 days after inoculation was subject to analysis of variance (ANOVA) and the means were com- pared by Fisher's protected least significant difference (LSD) at $P=0.05$ (39). Data from all experiments were analyzed using Statistix 8 (Analytical Software, Tallahassee, FL).

Effects of cultivar, wounding, and fruit maturity. Three different factors were studied in this experiment: cultivar (Hojiblanca, Picual, or Picudo), wounding (wounded or nonwounded), and two color classes of fruit (green or black). Fruit were inoculated by immersion for $30 \mathrm{~min}$ in a conidial suspension $\left(10^{6}\right.$ conidia/ml $)$ of isolate Col-10 and incubated as described above. Disease incidence was assessed 7 and 14 days after inoculation as above. The full factorial combination (three by two by two) of treatments was arranged in a completely randomized design. There were three replicates (humid chambers) per treatment and 20 fruit per replicate. The experiment was conducted twice, and data presented are the average of the two experiments because there was no significant difference $(P>0.05)$ between experiments. The area under the disease progress curve $\left(\mathrm{AUDPC}_{\mathrm{i}}\right)$ for disease incidence was calculated in each replication using the following formula:

$$
A U D P C_{i}=\sum_{i=1}^{n}\left[\left(I_{i+1}+I_{i}\right) / 2\right]\left(t_{i+1}-t_{i}\right)
$$

where I is the incidence (\%) at ith observation, $\mathrm{t}_{\mathrm{i}}$ is the time (days) at the $\mathrm{i}$ th observation, and $n$ is the total of number of observations. ANOVA was performed on the pooled $\mathrm{AUDPC}_{\mathrm{i}}$ data from the two experiments and treatment means were compared using Fisher's protected LSD at $P=0.05$.

Effects of cultivar, wounding, and inoculation method. Three different factors were studied: cultivar (Arbequina, Frantoio, Hojiblanca, Picual, and Picudo), wounding (wounded or nonwounded), and inoculation method (immersion or spray). The experiment was conducted twice; immature green fruit (color class 1) were used in the first trial and mature black fruit (color class 6) in the second trial. Fruit were inoculated by immersion or by spraying with a conidial suspension $\left(10^{6} \mathrm{co}-\right.$ nidia/ml) of isolate Col-87. Disease severity was assessed 7, 14, and 21 days after inoculation by using a 0 -to-5 rating scale, where $0=$ no visible symptoms, $1=$ visible symptoms affecting less than $25 \%$ of the fruit surface, $2=25$ to $50 \%, 3=50$ to $75 \%, 4=75$ to $100 \%$, and $5=$ fruit completely rotted, with abundant conidia in a gelatinous matrix (soapy fruit) or fruit with abundant white-gray mycelium on the surface. This severity scale was based on the different fruit symptoms observed in the previous experiments. There were three replicates (humid chambers) per treatment and 20 fruit per replicate. The full factorial combination (five by two by two) of treatments was arranged in a completely randomized design. A disease index (DI) and the area under the disease progress curve of severity $\left(\mathrm{AUDPC}_{\mathrm{s}}\right)$ were calculated in each replication. The DI was calculated using the following formula:

$$
D I=\left(\sum n_{i} \times i\right) / N
$$

where $i$ represents severity ( 0 to 5 ), $n_{i}$ is the number of fruit with the severity of $i$, and $N$ is the total number of fruit. For each treatment and repetition, the $\mathrm{AUDPC}_{\mathrm{s}}$ was calculated as the area under the curve of DI over time. The AUDPC $\mathrm{S}_{\mathrm{s}}$ was transformed to $\sqrt{A U D P C_{s}}$ when it was necessary for homogeneity of variance. ANOVA was performed on the $\mathrm{AUDPC}_{\mathrm{S}}$ data and treatment means were compared using Fisher's protected LSD at $P=0.05$.

Effect of inoculum density. To test the relationship between inoculum density and disease severity on fruit, green fruit (color class 1 ) of cvs. Hojiblanca and Picual were inoculated with a conidial suspension of isolate Col-87 at six different densities (10, $10^{2}, 10^{3}, 10^{4}, 10^{5}$, or $10^{6}$ conidia/ml). Fruit were incubated as described above. The DI and $\mathrm{AUDPC}_{\mathrm{s}}$ were calculated 7, 14, 21, and 28 days after inoculation in each replication. There were three replicates (humid chambers) per treatment and 20 fruit per replicate. Data presented are the average of the two experiments because there was no significant difference $(P>0.05)$ between them. The same experiment was repeated with Hojiblanca black fruit (color class 6). Treatments were compared using orthogonal contrasts for each inoculum density because there was a significant interaction between cultivar and inoculum density. The relationship between $\mathrm{AUDPC}_{\mathrm{s}}$ and the logarithm of inoculum density was calculated.

Cultivar susceptibility under field conditions. Disease response of the olive cultivars used in the artificial inoculation experiments was also assessed in a field trial of different cultivars at La Mina $\left(37.28^{\circ} \mathrm{N}, 4.26^{\circ} \mathrm{W}\right.$; province of Córdoba, southern Spain). In this orchard, 12 olive cultivars were arranged in a randomized complete block design with 12 blocks and one tree per cultivar in each block. All trees were planted in 1989 and were grown according to commercial practices, including the application of copper fungicides in April, October, and November 2005 to control diseases caused by Colletotrichum spp., Pseudocercospora cladosporioides, and Spilocaea oleagina (37).

Four trees of cvs. Arbequina, Frantoio, Hojiblanca, Picual, and Picudo exhibiting a similar level of infection were selected from the 12 replications of each cultivar to determine the incidence of fruit affected by Colletotrichum spp. after a severe anthracnose epidemic. Olive trees were harvested at different times when fruit were at the same maturity (color class 5 or 6) stage due to inherent differences of ripening among cultivars (6). The incidence (\%) of fruit with unequivocal symptoms of an- 
thracnose was determined in a sample of 2,000 fruit per tree. Percentage values of disease incidence (Y) were transformed into logit (Y) by the expression $\operatorname{Logit}(Y)=\operatorname{Ln}(Y / 100-Y)$ to make homogeneous variances (J. Moral and A. Trapero, unpublished data). ANOVA was performed on the transformed data and cultivar means were compared using Fisher's protected LSD at $P=0.05$. Disease incidence (\%) of affected fruit of each olive cultivar in the orchard trial was compared with the response of the same cultivars in artificial inoculations by the Pearson's correlation test.

\section{RESULTS}

Effect of fruit maturity. Fruit of cv. Hojiblanca developed anthracnose symptoms at six maturity stages (color classes 1 to 6). The first anthracnose symptoms were observed on inoculated wounded and nonwounded black fruit (color class 6) 4 days after inoculation. On green fruit (color class 1), the first lesions were associated with wounds 7 days after inoculation. The incidence of infected wounded or nonwounded fruit increased linearly with fruit maturity 7 days after inoculation (Fig. 1A). There was no significant difference between the slopes $(P=0.676)$ of the regression lines. Wounded fruit developed more anthracnose symptoms than nonwounded fruit at all maturity stages $(P<0.01)$. Fourteen days after inoculation, there was no effect of wounding, color class, or their interaction $(P>0.05$; Fig. 1B). At the end of the experiment, all infected fruit showed the characteristic general rot with abundant production of conidia in a gelatinous matrix ("soapy rot").

Effects of cultivar, wounding, and fruit maturity. Olive fruit of cvs. Hojiblanca, Picual, and Picudo were susceptible to $C$. acutatum. Four days after inoculation, initial anthracnose symptoms were observed on black fruit of cvs. Hojiblanca and Picudo with or without wounds. None of the noninoculated fruit developed symptoms. The effects of fruit maturity and cultivar on AUDPC $_{\mathrm{i}}$ were highly significant $(P<0.001)$, whereas wounding did not influence disease severity (Fig. 2). Based on inoculated green fruit, the order of cultivar susceptibility was Picudo > Hojiblanca $>$ Picual. When mature black fruit were inoculated, fruit of Picual were less susceptible than Picudo and Hojiblanca (Fig. 2).

Effects of cultivar, wounding, and inoculation method. Green fruit of cvs. Arbequina, Frantoio, Hojiblanca, Picual, and Picudo exhibited typical anthracnose symptoms. The pathogen sometimes produced abundant grayish-white mycelium on the fruit surface. Cultivar, wounding, inoculation method, and some interactions significantly affected $\mathrm{AUDPC}_{\mathrm{s}}$ (Table 1). Wounding did not influence disease severity when fruit were inoculated by spraying with the conidial suspension; however, when fruit were immersed in the conidial suspension, wounded fruit of all cultivars except Picual resulted in greater $\mathrm{AUDPC}_{\mathrm{s}}$ than those of nonwounded fruit. The inoculation method did not influence disease severity of fruit of cvs. Frantoio, Hojiblanca, and Picudo; however, fruit of cvs. Arbequina and Picual inoculated by immersion, with or without wounds, developed more symptoms than those inoculated by spraying. The cvs. Picudo and Frantoio were the most susceptible and most resistant to anthracnose, respectively. In general, the resistance level of the other cultivars was Picual $\geq$ Arbequina $>$ Hojiblanca (Table 1). Four weeks after inocula- tion, the level of disease on Frantoio was still low. However, when these fruit were evaluated 50 days after inoculation, the pathogen caused a general rot ("soapy rot") on most of the fruit.

Black fruit of cvs. Arbequina, Frantoio, Hojiblanca, Picual, and Picudo were susceptible to infection by $C$. acutatum. In all, 17 noninoculated fruit of Frantoio and 12 noninoculated fruit of Arbequina were infected by an Alternaria sp. Symptoms resulting from natural infections by an Alternaria sp. were easily recognized by the green-gray fluffy mycelium. Fruit infected by the Alternaria sp. were removed from the experiment. C. acutatum produced typical anthracnose lesions during
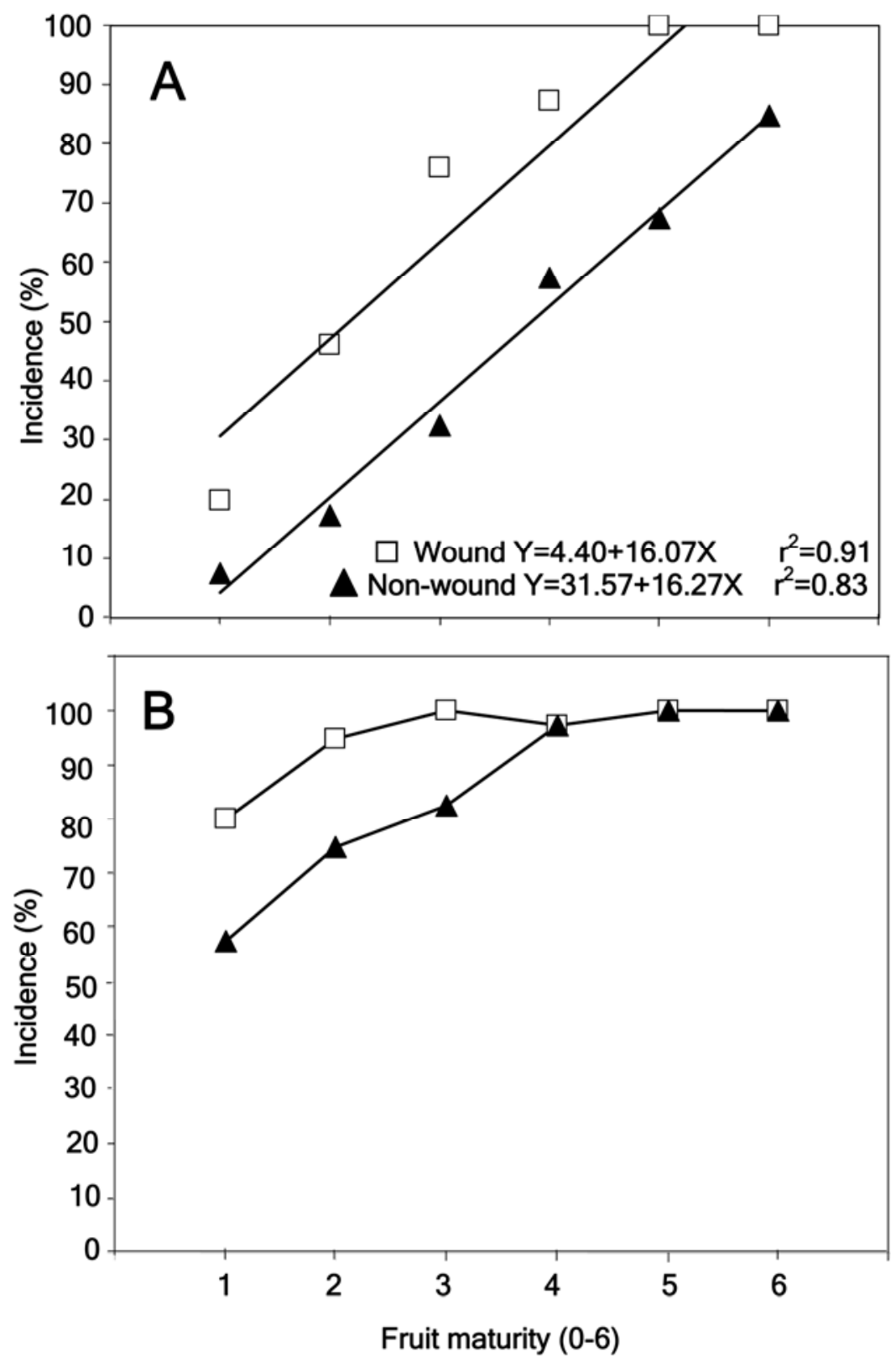

Fig. 1. Effect of fruit maturity on anthracnose incidence in 'Hojiblanca' olive fruit inoculated with isolate Col-10 of Colletotrichum acutatum A, 7 and B, 14 days after inoculation. Fruit maturity was assessed with a 1-to- 6 color class scale $(1=$ immature green fruit, $6=$ mature black fruit). For each color class, mean values were not significantly different according to Fisher's protected least significant difference test at $P=0.05$. 
the first week of evaluation; however, in the second and third weeks, affected fruit developed a white-gray mycelium of $C$. acutatum that covered the entire fruit. Cultivar, inoculation method, wound, and some interactions had a highly significant effect $(P<0.001)$ on the AUDPC s Table 1). Frantoio and Picudo were the most resistant and most susceptible cultivars, of Picudo were similar to symptoms on inoculated (Table 1). Inoculation by imrespectively, although symptoms on fruit Hojiblanca when wounded fruit were spray

mersion resulted in significantly $(P<$ $0.001)$ higher disease severity than inoculation by spraying when fruit were wounded prior to inoculation. However, there were no differences between inoculation methods when nonwounded fruit were used. Except for cvs. Frantoio and Picudo, wounding enhanced the development of anthracnose symptoms for both inoculation methods.

Effect of inoculum density. $C$. $a c u$ tatum caused typical lesions on fruit at all inoculum densities. The $\mathrm{AUPDC}_{\mathrm{s}}$ of in-

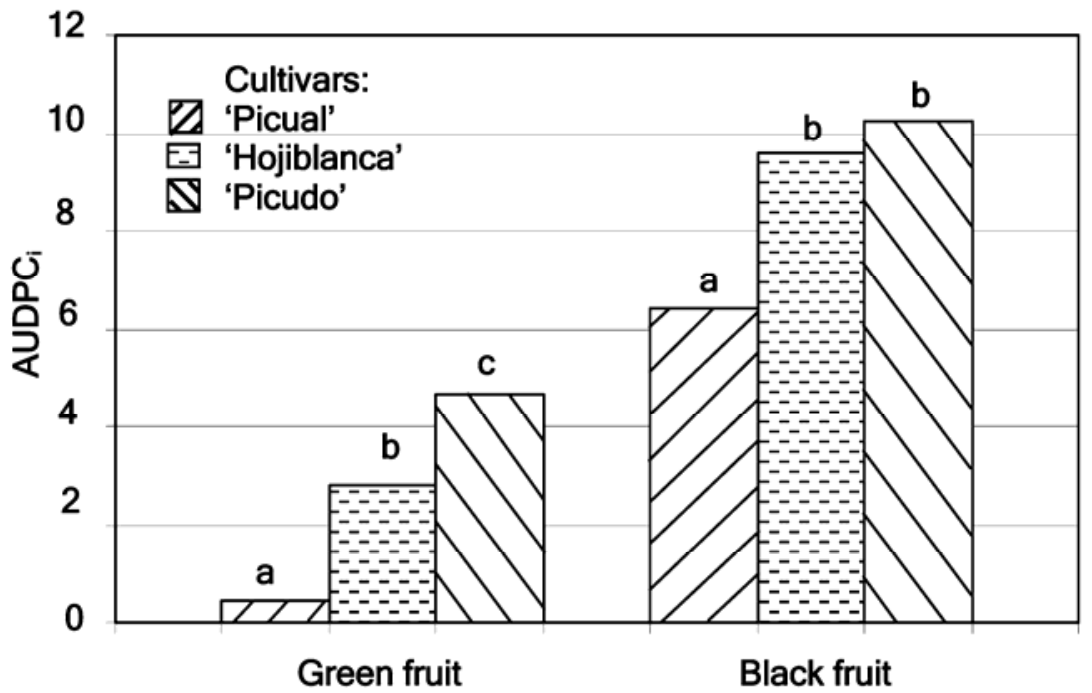

Fig. 2. Effect of fruit maturity and cultivar susceptibility on the area under the disease progress curve of incidence $\left(\mathrm{AUDPC}_{\mathrm{i}}\right)$ in olive fruit inoculated with isolate Col-10 of Colletotrichum acutatum. Two maturity classes (green and black fruit) and three olive cultivars (Hojiblanca, Picual, and Picudo) were used. Bars represent the average of 80 each wounded and nonwounded fruit. For each maturity class, mean values with the same letter are not significantly different according to Fisher's protected least significant difference test at $P=0.05$.

Table 1. Effects of cultivar (Cv), inoculation method (Inoc), fruit maturity, and wounding (Wound) on anthracnose symptoms of olive fruit inoculated with Colletotrichum acutatum

\begin{tabular}{|c|c|c|c|c|}
\hline \multirow[b]{3}{*}{ Inoc, cultivar ${ }^{\mathrm{Z}}$} & \multicolumn{4}{|c|}{$\operatorname{AUDPC}_{\mathrm{s}}{ }^{\mathbf{y}}$} \\
\hline & \multicolumn{2}{|c|}{ Green fruit } & \multicolumn{2}{|c|}{ Black fruit } \\
\hline & Nonwounded & Wounded & Nonwounded & Wounded \\
\hline \multicolumn{5}{|l|}{ Spray } \\
\hline Picudo & $69.4 \mathrm{a}$ & $86.9 \mathrm{a}$ & $71.2 \mathrm{a}$ & $74.7 \mathrm{a}$ \\
\hline Hojiblanca & $44.1 \mathrm{~b}$ & $45.9 \mathrm{~b}$ & $62.4 \mathrm{~b}$ & $69.0 \mathrm{ab}$ \\
\hline Arbequina & $14.8 \mathrm{c}$ & $27.5 \mathrm{c}$ & $58.3 \mathrm{bc}$ & $60.7 \mathrm{~b}$ \\
\hline Picual & $14.1 \mathrm{c}$ & $13.2 \mathrm{~d}$ & $51.3 \mathrm{c}$ & $65.2 \mathrm{~b}$ \\
\hline Frantoio & $2.4 \mathrm{~d}$ & $3.1 \mathrm{e}$ & $28.0 \mathrm{~d}$ & $21.1 \mathrm{c}$ \\
\hline \multicolumn{5}{|l|}{ Immersion } \\
\hline Picudo & $78.2 \mathrm{a}$ & $82.2 \mathrm{a}$ & $80.0 \mathrm{a}$ & $86.4 \mathrm{a}$ \\
\hline Hojiblanca & $38.4 \mathrm{~b}$ & $44.2 \mathrm{~b}$ & $61.6 \mathrm{~b}$ & $75.6 \mathrm{~b}$ \\
\hline Arbequina & $31.4 \mathrm{~b}$ & $42.8 \mathrm{bc}$ & $43.3 \mathrm{c}$ & $75.9 \mathrm{~b}$ \\
\hline Picual & $30.0 \mathrm{~b}$ & $28.4 \mathrm{c}$ & $64.6 \mathrm{~b}$ & $77.9 \mathrm{~b}$ \\
\hline Frantoio & $3.3 \mathrm{c}$ & $9.7 \mathrm{~d}$ & $33.0 \mathrm{c}$ & $49.0 \mathrm{c}$ \\
\hline \multicolumn{5}{|l|}{ Interactions } \\
\hline $\mathrm{Cv} \times \mathrm{Inoc}$ & $\ldots$ & 0.001 & $\ldots$ & 0.0090 \\
\hline $\mathrm{Cv} \times$ Wound & $\ldots$ & 0.0289 & $\ldots$ & 0.0011 \\
\hline Inoc $\times$ Wound & $\ldots$ & NS & $\ldots$ & 0.0000 \\
\hline $\mathrm{Cv} \times \operatorname{Inoc} \times$ Wound & $\ldots$ & NS & $\ldots$ & 0.0289 \\
\hline
\end{tabular}

${ }^{y}$ Area under disease progress curve of severity. Disease severity was assessed 7, 14, and 21 days after inoculation by using a 0 -to- 5 rating scale; mean values of each repetition were used to calculate the AUDPC $_{\mathrm{s}}$ over time. Three wounds ( $2 \mathrm{~mm}$ deep and $0.8 \mathrm{~mm}$ wide) were made in each fruit with a sterilized needle before inoculation. In each column, mean values followed by the same letter are not significantly different according to Fisher's protected least significant difference at $P=0.05$; NS $=$ not significant.

${ }^{\mathrm{z}}$ Two inoculation methods were tested: spray with or immersion in a spore suspension $\left(10^{6}\right.$ conidia $\left./ \mathrm{ml}\right)$. fected fruit increased with the density of inoculum from 10 to $10^{6}$ conidia/ml. When green fruit of cvs. Hojiblanca and Picual were inoculated, the cultivar-inoculum density interaction had a significant $(P<$ 0.05) effect on $\mathrm{AUDPC}_{\mathrm{s}}$ (Fig. 3A). Green fruit of cv. Hojiblanca were more susceptible than green fruit of cv. Picual when inoculated with $10^{4}, 10^{5}$, or $10^{6}$ conidia $/ \mathrm{ml}$. The response of Picual was not influenced by inoculum density (Fig. 3A). When black fruit of Hojiblanca were inoculated, the $\mathrm{AUDPC}_{\mathrm{s}}$ increased linearly with the logarithm of inoculum density $\left(r^{2}=0.837\right.$; $P<0.001$; Fig. 3B).

Cultivar susceptibility under field conditions. Fruit of cvs. Arbequina, Frantoio, Hojiblanca, Picual, and Picudo were infected by Colletotrichum spp. under field conditions, although two of four trees of Frantoio did not show any symptoms. There was a significant difference $(P<$ $0.001)$ in the susceptibility of all cultivars to anthracnose (Table 2). There was a significant correlation between disease incidence $\mathrm{Y}(\%)$ in the orchard trial and AUPDC $_{\mathrm{s}}$ in artificial inoculations with green inoculated fruit. The best correlation $(P=0.0007)$ was between field data and data from the assay on nonwounded green fruit inoculated by spraying (Table 3 ).

\section{DISCUSSION}

Olive anthracnose was reported for the first time in 1899 by Almeida (4) in Portugal. Although the etiology of anthracnose has been elucidated $(2,25,26,40)$, little information exists on the different factors that affect infection of olive fruit by $C$. acutatum $(18,27)$. In this study, olive fruit of several cultivars grown in Spain were susceptible to infection by $C$. acutatum under artificial inoculation, although symptoms were not always typical of field infections. For example, infected fruit did not mummify, possibly due to the high humidity in the inoculation chambers. Abundant mycelia were frequently observed on inoculated black fruit, another atypical symptom indicative of high humidity (40). Mycelial growth is not typically observed under field conditions $(10,11,41)$. None of the noninoculated fruit developed symptoms of anthracnose but latent infections by an Alternaria sp. were detected in fruit of cvs. Arbequina and Frantoio. Infection of olive fruit by an Alternaria sp. seemed to be associated with a particular orchard (La Venta del Llano, Jaén Province), because noninfected fruit of other cultivars were collected from another location (Jarata, Córdoba Province). Infection of olive fruit by the Alternaria sp. has been previously described but its importance appears to be limited $(9,30)$.

Fruit maturity, cultivar, wounds, inoculum density, and their interactions influenced infection of olive fruit by $C$. $a c u$ tatum. Cultivar and fruit maturity (color 
class) were the most influential factors. In general, susceptibility to $C$. acutatum increased linearly with fruit maturity, although fruit of the susceptible cv. Picudo was consistently susceptible regardless of age or other factors. The greater susceptibility of mature fruit may be related to the loss of one or several host resistance mechanisms that are present in young, immature fruit $(21,36)$. Although these resistance mechanisms have not been studied in olive anthracnose, it has been suggested that higher concentrations of phenolic compounds in immature olive fruit than mature ones may account for their resistance to several olive pests and diseases (38).

Trees severely affected by anthracnose are characterized by lower yields, fruit that ripen more quickly the next season, and fruit that develop anthracnose earlier in the year (J. Moral and A. Trapero, unpublished data). In our trials, immature fruit more accurately reflected susceptibility or resistance of cultivars to anthracnose than mature fruit. Immature and nonwounded olive fruit have been successfully used to assess differences in virulence among isolates of Colletotrichum spp. $(3,32,33,35)$.
Wounding influences infection by Colletotrichum spp. even though direct penetration of plant cuticles is common $(5,17,18$, $27,35,40$ ). Although wounding is not necessary for olive fruit infection, the severity of symptom expression as well as the rate of colonization is enhanced when fruit are wounded $(14,18,19)$. Mateo-Sagasta (27) suggested that resistance of some cultivars in the field could change if fruit were wounded by the olive fly (Bactrocera oleae). In our study, there was an interaction between wounding of fruit and inoculation method. In general, more disease developed when wounded fruit were inoculated by immersion in a conidial suspension than in the other experimental conditions. This method probably favored the introduction of inoculum through wounds in the fruit. Although the susceptibility of fruit of different cultivars varied and the highest disease severity levels were reached when mature fruit were inoculated by immersion, differences among the cultivars were more pronounced when immature fruit were inoculated by spraying. This inoculation method is also closer to the natural inoculation process in which conidia of Colle-
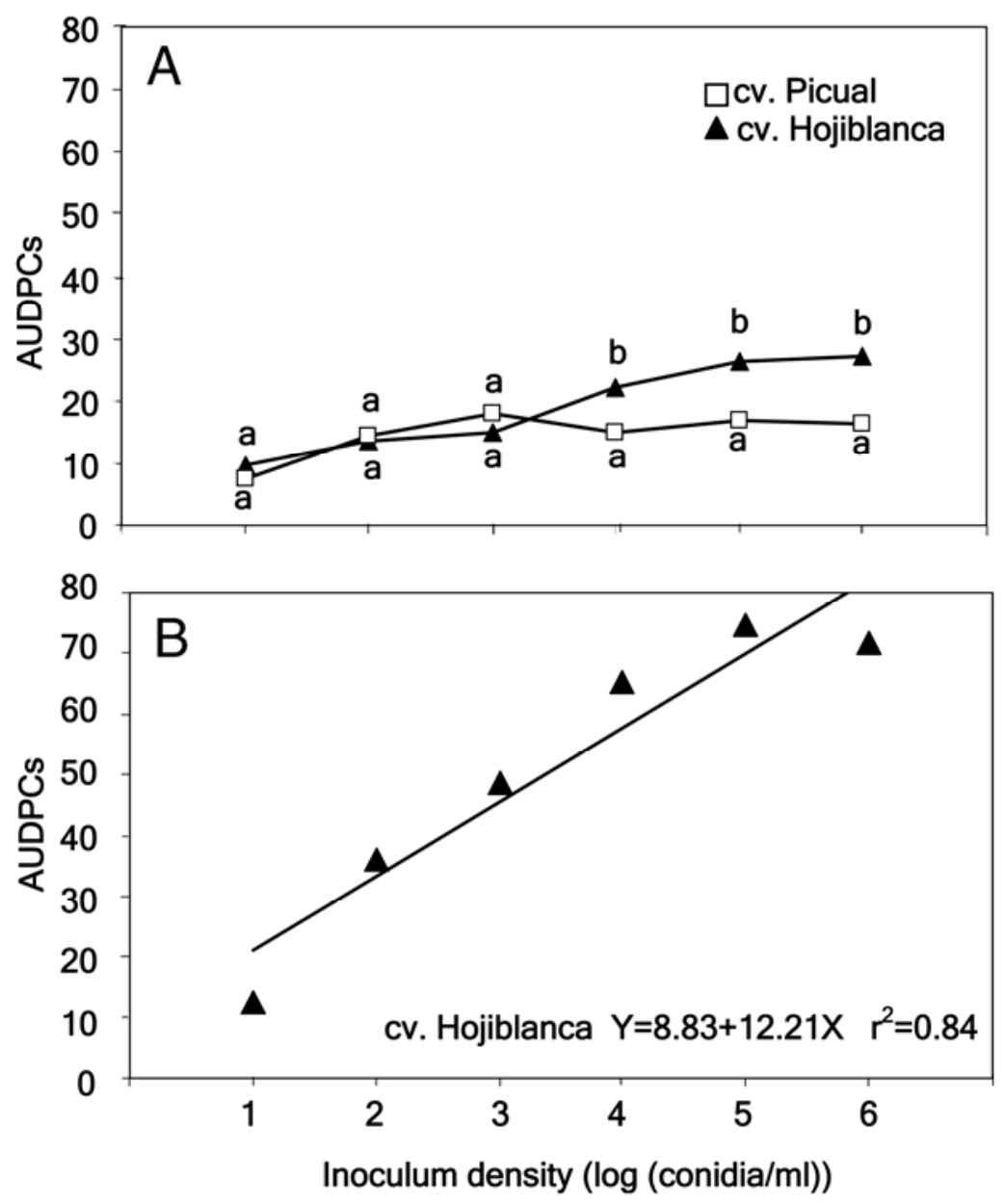

Fig. 3. Effect of inoculum density on the area under the disease progress curve of severity (AUDPC $)_{\mathrm{s}}$ on olive fruit inoculated with isolate Col-87 of Colletotrichum acutatum. A, Green fruit of cvs. Hojiblanca and Picual. B, Black fruit of Hojiblanca. For each inoculum density, mean values with the same letter are not significantly different according to orthogonal contrasts at $P=0.05$.

totrichum spp. are deposited on the fruit surface by rain droplets.

The severity of anthracnose on olive fruit increases with increases in inoculum density $(13,34)$. In our study, anthracnose symptoms developed on olive fruit inoculated with a very low inoculum density (approximately 10 conidia/fruit). However, differences in resistance between the cvs. Hojiblanca and Picudo were more easily detected when higher inoculum densities $\left(10^{4}, 10^{5}\right.$, and $10^{6}$ conidia/ml $)$ were used.

In general, both the detached olive fruit assay and field observations indicate that the most resistant to the most susceptible olive cultivars are Frantoio, Picual, Arbequina, Hojiblanca, and Picudo, respectively, consistent with previous observations $(29,42)$. The laboratory assay with immature and nonwounded fruit was the assay most in agreement with the susceptibility of the cultivars in the field. In contrast to these studies, Frantoio was considered susceptible to anthracnose in Argentina (11), possibly due to a misidentification of the cultivar, which occurs frequently among cultivars of $O$. europaea (6). Anthracnose incidence measured as the percentage of affected fruit in each tree was a good method to assess olive anthracnose under field conditions. This evaluation is best done when olive fruit reach maturity (color class 5 to 6). When fruit are past maturity, all cultivars may show complete rot ("soapy rot"), independent of their susceptibility to anthracnose.

Our results demonstrate the importance of using less susceptible or late-maturing cultivars and early harvest as strategies to control olive anthracnose. In regions favoring olive anthracnose, recommended control practices include early harvesting of olives fruit (41) and using cultivars that ripen more slowly (8). Fungicides have limited use because $C$. acutatum has low sensitivity to copper fungicides (37) and

Table 2. Incidence of anthracnose caused by Colletotrichum acutatum in five olive cultivars under field conditions ${ }^{x}$

\begin{tabular}{|c|c|}
\hline Cultivar $^{\mathrm{y}}$ & Affected fruit $(\%)^{\mathrm{z}}$ \\
\hline Picudo & $85.7 \mathrm{e}$ \\
\hline Hojiblanca & $54.5 \mathrm{~d}$ \\
\hline Arbequina & $10.7 \mathrm{c}$ \\
\hline Picual & $4.4 \mathrm{~b}$ \\
\hline Frantoio & $0.05 \mathrm{a}$ \\
\hline
\end{tabular}

${ }^{x}$ Four trees of each olive cultivar showing a similar infection level were selected in an orchard trial affected by a severe epidemic of anthracnose in 2005.

${ }^{y}$ Five olive cultivars differing in anthracnose susceptibility were selected from previous studies (29).

${ }^{\mathrm{z}}$ Percentage of affected fruit was calculated in a sample of 2,000 fruit per tree. All mean values are significantly different according to Fisher's protected least significant difference test at $P=$ 0.05 . Percentage data $(Y)$ were transformed by the logit function, $\operatorname{Logit}(Y)=\operatorname{Ln}(Y / 100-Y)$, for homogeneity of variance. 
Table 3. Correlation between anthracnose incidence in five olive cultivars in an orchard trial and disease severity of olive fruit of the same cultivars inoculated with Colletotrichum acutatum

\begin{tabular}{lcc}
\hline & \multicolumn{2}{c}{ Pearson's test parameter $^{\mathbf{y}}$} \\
\cline { 2 - 3 } Inoculation treatment $^{\mathbf{z}}$ & $\boldsymbol{r}$ & $\boldsymbol{P}$ value \\
\hline Green fruit + spraying + nonwounded & 0.993 & 0.0007 \\
Green fruit + spraying + wounded & 0.972 & 0.0055 \\
Green fruit + immersion + nonwounded & 0.897 & 0.0391 \\
Green fruit + immersion + wounded & 0.899 & 0.0381 \\
Black fruit + spraying + nonwounded & 0.786 & 0.1151 \\
Black fruit + spraying + wounded & 0.646 & 0.2394 \\
Black fruit + immersion + nonwounded & 0.787 & 0.1140 \\
Black fruit + immersion + wounded & 0.638 & 0.2463 \\
\hline
\end{tabular}

y Correlation coefficient $(r)$ and probability value $(P$ value) using the Pearson's correlation test.

${ }^{\mathrm{z}}$ Inoculations were made using two fruit maturity classes (green or black), two inoculation methods (spraying or immersion), and two fruit wounding treatments (wounded or nonwounded).

the use of organic fungicides in olive orchards is limited during the fall and winter in Spain (12).

\section{ACKNOWLEDGMENTS}

This research was funded by the Spanish Ministry of Education and Science (projects AGL20001725 and AGL2004-7495). We thank the International Olive Oil Council (IOOC) for granting K. Bouhmidi a stay at the University of Córdoba for 1 year; F. Luque for her skillful technical assistance in the laboratory; B. Jiménez and F. Ruiz for their expert assistance in the field work; and T. J. Michailides, J. C. Jiménez-Melgar, and W. J. Kaiser for critical review of the manuscript.

\section{LITERATURE CITED}

1. Agosteo, G. E., Macri, C., Faedda, R., Pennisi, A. M., Cacciola, S. O., and Magnano di San Lio, G.. 2003. Epidemic outbreaks of olive anthracnose in central Italy. J. Plant. Pathol. 85:280.

2. Agosteo, G. E., Magnano di San Lio, G., Cacciola, S. O., and Frisillo, S. 2002. Characterisation of the causal agent of olive anthracnose in southern Italy. Acta Hortic. 586:713-716.

3. Agosteo, G. E., and Penninsi, A. M. 1994. Confronto tra isolati di Colletotrichum gloeosporioides ottenuti da olivo e da agrumi in Calabria. Micol. Ital. 1:76-80.

4. Almeida, M. J. V. 1899. La gaffa des olives en Portugal. Bull. Soc. Mycol. France 15:90-94.

5. Bailey, J. A., O'Connel, R. J., Pring, R. J., and Nash, C. 1992. Infection strategies of Colletotrichum species. Pages 88-120 in: Colletotrichum: Biology, Pathology and Control. J. A. Bailey and M. J. Jeger, eds. CAB International, Wallingford, Oxon, U.K.

6. Barranco, D. 2008. Variedades y patrones. Pages 63-92 in: El cultivo de olivo. D. Barranco, R. Fernández-Escobar, and L. Rallo, eds. Coedición Junta de Andalucía and Mundi-Prensa, Madrid.

7. Biggs, A. R., and Miller, S. S. 2001. Relative susceptibility of selected apple cultivars to Colletotrichum acutatum. Plant Dis. 85:657660.

8. Bompeix, G., Julio, E. V. R., and Phillips, D. H. 1988. Glomerella cingulata (Stoneman) Spaulding et v. Schrenk. Pages 373-376 in: Manual de enfermedades de las plantas. I. M. Smith, J. Dunez, R. A. Lelliot, D. H. Phillips, and S. A. Archer, eds. Mundi-prensa, Madrid.

9. Bottalico, A., and Logrieco, A. 1993. Mycotoxins in Alternaria alternata infected olive fruits and their possible transfer into oil. EPPO Bull. 23:473-479.
10. Cacciola, S. O., Pane, A., Agosteo, G. E., and Magnano di San Lio, G. 1996. Osservazioni sull' epidemiologia dell'anthracnosi dell'olivo in Calabria. Inf. Fitopatol. 6:27-32.

11. de Andrés, F. 1991. Enfermedades y plagas del Olivo. Riquelme y Vargas Ediciones S.L., Jaén, Spain.

12. de Liñán, C. 2007. Vademecum de productos fitosanitarios. Ediciones Agrotécnicas. Madrid.

13. Dillard, H. R. 1989. Effect of temperature, wetness duration, and inoculum density on infection and lesion development of Colletotrichum coccodes on tomato fruit. Phytopathology 79:1063-1066.

14. Freeman, S., Horowitz, S., and Sharon, A. 2001. Pathogenic and nonpathogenic lifestyles in Colletotrichum acutatum from strawberry and other plants. Phytopathology 91:986-992.

15. García-Figueres, F. 1991. Repilos del olivo: ataque al fruto. Phytoma España 25:31-36.

16. García-Figueres, F. 1998. Micosis de las aceitunas y su incidencia en la calidad del aceite. Phytoma España 102:171-175.

17. García-Figueres, F., Pedret, E., Marco, V., and Duatis. J. J. 1997. Sensibilidad de diversas variedades de olivo al hongo Colletotrichum gloeosporioides. Fruticult. Prof. 88:60-63.

18. Graniti, A., Frisullo, S., Pennisi, A.M., and Magnano di San Lio, G. 1993. Infections of Glomerella cingulata on olive in Italy. EPPO Bull. 23:457-465

19. Graniti, A., and Laviola, C. 1981. Sguardo generale alle malattie parassitarie dell'olivo. Inf. Fitopatol. 31:77-92.

20. Hong, J. K., and Hwang, B. K., 1998. Influence of inoculum density, wetness duration, plant age, inoculation method, and cultivar resistance on infection of pepper plants by Colletotrichum coccodes. Plant Dis. 82:10791083.

21. Jeffries, P., Dodd, J. C., Jeger, M. J., and Plumbey, R. A. 1990. The biology and control of Colletotrichum species on tropical fruit crops. Plant Pathol. 39:343-366.

22. Kader, A., Nanos, G. D., and Kerbel, E. 1990. Storage potential of fresh 'Manzanillo' olives. Calif. Agric. 44:23-24.

23. Loprieno, N., and Tenerini, I. 1960. Studies on Gloeosporium olivarum, the cause of 'leprosy' of olive. Phytopathol. Z. 39:262-290.

24. M.A.P.A. 2006. Encuesta sobre superficie y rendimiento de cultivos. Ministerio de Agricultura, Pesca y Alimentación, Madrid.

25. Martín, M. P., and García-Figueres, F. 1999. Colletotrichum acutatum and C. gloeosporioides cause anthracnose on olives. Eur. J. Plant
Pathol. 105:733-741.

26. Martín, M. P., García-Figueres, F., and Trapero, A. 2002. Iniciadores específicos para detectar las especies de Colletotrichum causantes de la antracnosis de los olivos. Bol. San. Veg. Plagas 28:43-50.

27. Mateo-Sagasta, E. 1968. Estudios básicos sobre Gloeosporium olivarum Alm. (Deuteromiceto Melanconial). Bol. Patol. Veg. Entomol. Agric. 30:31-135.

28. Menge, J. A., and Ploetz, R. C. 2003. Diseases of avocado. Pages 35-71 in: Diseases of Tropical Fruit Crops. R. C. Ploetz, ed. CAB International, Wallingford, Oxon, UK.

29. Moral, J., Ávila, A., López-Doncel, L. M., Alsalimiya, M., Oliveira, R., Gutiérrez, F., Navarro, N., Bouhmidi, K., Benali, A., Roca, L., and Trapero, A. 2005. Resistencia a los Repilos de distintas variedades de olivo. Vida $\mathrm{Ru}$ ral 208:34-40.

30. Moral, J., de la Rosa, R., León, L., Barranco, D., Michailides, T. J., and Trapero, A. High susceptibility of the olive cultivar FS-17 to $\mathrm{Al}$ ternaria alternata in southern Spain. Plant Dis. 92:1252.

31. Moral, J., Oliveira, R., Kaiser, W. J., and Trapero, A. 2007. Susceptibility of olive flowers, fruits, leaves and branches to infection by $\mathrm{Col}$ letotrichum species causing olive anthracnose. (Abstr.) Phytopathology 97:S79.

32. Moral, J., Oliveira, R., Tello, J. C., and Trapero, A. 2006. Pathogenic characterization of isolates of Colletotrichum species causing olive anthracnose. Pages 521-525 in: Proc. 12th Congr. Mediterr. Phytopathol. Union, Rhodes Island, Greece.

33. Mugnai, L., Surico, G., and Rogazzi, A. 1993. Glomerella cingulata on olive in India: morphological and pathological notes. EPPO Bull 23:449-455.

34. Noe, J. P., and Starkey, T. E. 1982. Relationship of apple fruit maturity and inoculum concentration to infection by Glomerella cingulata. Plant Dis. 66:379-380.

35. Oliveira, R. 2003. Etiología y control químico de la Aceituna Jabonosa causada por Colletotrichum spp. Ph.D. thesis, Universidad de Córdoba, Córdoba, Spain.

36. Prusky, D. 1996. Pathogen quiescence in postharvest diseases. Annu. Rev. Phytopathol 34:413-434.

37. Roca, L. F., Moral, J., Viruega, J. R., Ávila, A., Oliveira, R., and Trapero, A. 2007. Copper fungicides in the control of olive diseases. Olea 26:48-50.

38. Ryan, D., and Robards, K. 1998. Phenolic compounds in olives. Analyst 123:31-44.

39. Steel, R. G. D., and Torrie, J. H. 1985. Bioestadística. McGraw-Hill, Bogotá, Colombia.

40. Talhinhas, P., Sreenivasaprasad, S., NevesMartins, J., and Oliveira, H. 2005. Molecular and phenotypic analyses reveal association of diverse Colletotrichum acutatum groups and a low level of $C$. gloeosporioides with olive anthracnose. Appl. Environ. Microbiol. 71:29872998.

41. Trapero, A., and Blanco, M. A. 2008. Enfermedades. Pages 595-656 in: El cultivo de olivo. D. Barranco, R. Fernández-Escobar, and L. Rallo, eds. Coedición Junta de Andalucía/Mundi-Prensa, Madrid.

42. Trapero, A., Viruega, J. R., and Luque, F. 1998. Incidencia de la podredumbre de aceitunas causada por Colletotrichum gloeosporioides sobre cultivares de olivo. Page 107 in: IX Congreso de la Sociedad Española de Fitopatología. SEF, Salamanca, Spain. 